\title{
MAXŮV CYKLUS OBRAZOVÝCH FANTAZIÍ K HUDEBNÍM SKLADBÁM
}

Mnichovský malíř českého původu Gabriel von Max (1840-1915) se stal jednou z „hvězd“" proslulé Mnichovské školy ve druhé polovině 19. století. Jeho prestižní společenské postavení bylo stvrzeno udělením nižšího šlechtického titulu u př́ležitosti jeho 60. narozenin v roce 1900; byt' to bylo paradoxně $\mathrm{v}$ zenitu jeho veřejné umělecké kariéry, jež kulminovala již v 70.-80. letech 19. věku. Hlavní prŕíčinou mimořádné obliby Maxových obrazů byla patrně autorova schopnost vzbudit u diváků empatii a psychologickou rezonanci, a to až do té míry, že jej část kritiky obviňovala $\mathrm{z}$ cíleného kalkulu a snahy o vnější efekt. ${ }^{1}$ Max nesdílel dobově rozšířený názor o didaktickém a výchovném poslání umění; místo toho u svých diváků usiloval především o silnou citovou odezvu, podobně jako kdyby četli lyrickou poezii, nebo poslouchali hudbu. Proto také, jak bude doloženo, některá z jeho výtvarných děl obsahují přímé literární a hudební odkazy a směřují k efektu synestézie.

Gabriel von Max patří k druhdy slavným umělcům, kteří na dlouhá desetiletí upadli téměř do zapomnění, byt' sběratelský zájem o jeho dílo nikdy nepominul. Vzhledem k zásadnímu přehodnocení významu umění 19. století historiografií umění ve 20. století (oproti původnímu ocenění dobové kritiky) to nemůže překvapit, avšak již delší dobu dochází k novému přehodnocení této historiografické selekce, orientované výhradně podle kritéria vývojového progresu, a tudíž někteří ze „slavných zapomenutých“ jsou opět připomínáni. Jedním z nich je Gabriel von Max, jemuž byla věnována pozornost již před čtyřiceti lety v průkopnické knize o salónním malířství, ale o němž byly vydány moderní monografie doprovázející výstavy jeho díla až v posledních čtyřech letech. ${ }^{2}$

1 WEBEROVÁ, Susanne. Dobová recepce díla Gabriela von Maxe v Německu. In Gabriel von Max (1840-1915). Aleš Filip - Roman Musil (eds.). Řevnice: Arbor vitae, 2011, s. 260-283, zde s. 264.

2 ČELEBONOVIĆ, Aleksa. Bürgerlicher Realismus. Meisterwerke der Salonmalerei. Berlin: Propyläen-Verlag, 1974; Gabriel von Max. Malerstar, Darwinist, Spiritist. Karin Althaus - Helmut Friedel (eds.). München: Hirmer, 2010; Gabriel von Max (1840-1915), op. cit.; Gabriel von Max. Be-tailed cousins and phantasms of the soul. Jo-Anne Birnie Danzker 
Tento článek je věnován Maxovu ranému dílu, cyklu 12-13 lavírovaných kreseb, jež se vážou ke konkrétním hudebním skladbám. Přestože jej Gabriel Max vytvořil ještě v době svých studií, ve stáří 21-22 let, je považován za jeho zásadní dílo, a to z několika důvodů, jež budou záhy objasněny. Dílu byla věnována poměrně velká pozornost ve třech Maxových monografích: jednak u Mikuláše Lehmanna už v letech 1888 a 1890, jednak v disertační práci Margaret Mary Richter v New Yorku v roce 1998, a jednak v mnichovské monografii z roku 2010 v př́ispěvku Andrey Gottdang. ${ }^{3}$ Stejná autorka předtím napsala vůbec první systematické pojednání o hudební inspiraci v maliŕrství 19. století, jež nám bude oporou pro komparace. ${ }^{4} \mathrm{~V}$ tomto př́spěvku bude Maxův raný cyklus nově analyzován za pomoci dosud nevyužitých pramenů z jeho pozůstalosti v archívu umění Germánského národního muzea v Norimberku. ${ }^{5} \mathrm{~V}$ závěru budou reflektovány také další hudební motivy v jeho výtvarném díle. Z muzikologického hlediska může být tento článek př́nosný pro studium recepce hudby v 19. století.

\section{Geneze cyklu}

V roce 1875 Gabriel von Max sepsal pro propagátora svého díla, prítele Agathona Klemta vlastní životopis, ovšem ve zlehčujícím, humorně-ironickém podání. ${ }^{6}$ Píše o št'astném dětství v Praze, jež ukončila předčasná smrt otce, sochaře Josefa Maxe; ten podlehl choleře, když chlapci bylo 15 let. $V$ tomto věku nastoupil na „druhořadou“ uměleckou Akademii v Praze, kde se prý „naučil flákáni". Neuspokojilo ho ani následné studium na Akademii ve Vídni, ukončené rozhodnutím jejího ředitele Christiana Rubena o odnětí stipendia, nebot' Max se mu prý jevil ,jako líný uzavřený člověk". Následující vyprávění se vztahuje k létům 1861-1862. Max vzpomíná: „Nyní jsem jel do Prahy za matkou a obštast-

(ed.). Seattle: Frye Art Museum, 2011. (Uvedené tři publikace doprovázely Maxovy výstavy ve Städtische Galerie im Lenbachhaus und Kunstbau v Mnichově, v Západočeské galerii v Plzni a ve Frye Art Museum v Seattlu, ale nejsou koncipovány jako výstavní katalogy.)

3 MANN (LEHMANN), Nicolaus. Gabriel Max. Eine kunsthistorische Skizze. 2. upr. vyd. J. J. Weber, Leipzig: 1890, s. 12-16; RICHTER, Margaret Mary. Gabriel Max. The Artist, the Darwinist and the Spiritualist. (phil. dissertation, vedoucí práce Robert Rosenblum) New York University, 1998, s. 67-85; GOTTDANG, Andrea. „Vom Schalle geweckte Träume.“ Gabriel von Max und die Musik. In Gabriel von Max. Malerstar, Darwinist, Spiritist, op. cit., s. 56-63.

4 GOTTDANG, Andrea. Vorbild Musik. Die Geschichte einer Idee in der Malerei im deutschsprachigen Raum 1780-1915. München: Deutscher Kunstverlag, 2004. O Maxově cyklu: tamtéž, s. 245-246, viz též pozn. 15.

5 Germanisches Nationalmuseum v Norimberku, Deutsches Kunstarchiv, Nachlass Max, Gabriel von (dále jen: GNM Norimberk, DKA, NL Max). Vycházíme především z pramenů doplněných do pozůstalosti v letech 2008 a 2010. Následně byla v roce 2012 Maxova pozůstalost reinventarizována.

$6 \quad$ MAX, Gabriel von. Texty z pozůstalosti I. In Gabriel von Max (1840-1915), op. cit, s. 7887, zde s. 78-81. Překlad autora studie. 
nil jsem svět kreslenými fantazijními obrazy, které byly dobře míněny a špatně udélány. Kupodivu to byla křižovatka pro moji budoucnost." Mikuláš Lehmann, který svůj životopis G. Maxe patrně sepisoval v součinnosti se samotným umělcem, to popsal obdobně: „Dieses originelle Jugendwerk macht zwar noch den Eindruck des Mangels an technischer Reife, trägt aber trotz mancher Härten und Unvollkommenheiten unverkennbar den Stempel des Genius. “7 Nabídl také vysvětlení otázky, proč toto dílo zapůsobilo na Maxovu budoucnost; bylo sice přijato kontroverzně, když mnozí je povařovali za přehnané (,überspannt"), ale kontroverze $\mathrm{v}$ tisku jen povzbudily zájem o ně. Lehmann tvrdí, že dnes ( $\mathrm{tj} . \mathrm{v}$ roce 1890) už každý ocení ,silu vcitění, odvahu fantazie a toku myšlenek, v nichž se již jevil rozvíjejicí se mladý umělecký duch" “. Dílo skutečně nebylo považováno za méně hodnotnou juvenilii, ale za důležitý tvůrčí čin, o čemž svědčí skutečnost, že během tří decennií od prvního vydání bylo vydáno ještě dvakrát.

Zajímavá je otázka kreslírského provedení tohoto cyklu; ten podle Lehmanna sice vzešel z ducha odboje proti strnulému, suchopárnému akademismu, ale na druhé straně je akademické ovládnutí kreslených historií základním předpokladem jeho realizace. Ovšem nazarénské akademické postupy, které tehdy na vídeňské akademii určovaly směr, Max obohatil oživujícími detaily, a zejména ikonografickými inovacemi. Je nutno dodat, že ani v rámci nazarénství není vždy na místě představa strnulosti či „zmrzlého děje“, např. Maxem obdivovaný Josef von Führich, u nějž si však nemohl dovolit ve Vídni studovat, ${ }^{9}$ spojoval nazarénskou idealizaci s živými dějovými akcenty, jak přesvědčivě dokládá jeho slavná a často napodobovaná Kř́žová cesta.

Gabriel von Max vytvořil svůj cyklus kreseb ve Vídni v roce 1861 a dokončil jej v následujícím roce v Praze; 8 kreseb datoval do roku 1861 a 3 do roku 1862, připojený autorský výklad byl sepsán či dokončen v Praze v červnu 1862. Maxův cyklus poprvé vydalo vídeňské nakladatelství Jägermayer \& Companie v roce 1862, následovala dvě další vydání, kabinetní (na rozdíl od prvního velkoformátového o velikosti $65 \times 49 \mathrm{~cm}$ ), a sice ve Vídni v nakladatelství Miethke (rok vydání neuveden) a dále v Mnichově u Theodora Strockera v roce 1885. Zatímco první dvě vydání obsahovala třináct listů kreseb, třetí jen dvanáct a v pozměněném pořadí, původní název Phantasie-Bilder zu Tonstücken byl redukován na Bilder zu Tonstücken. ${ }^{10}$ Pro všechna vydání byla zvolena forma fotografické reprodukce kreseb. ${ }^{11}$ Dvě z nich se zachovaly v originále: jednak 3 . list cyklu (Př. 1) k Beethovenově klavírní Sonátě měsičního světla (opus 27), který je uložen v Ostdeutsche Galerie v Regensburgu, a jednak 5. list cyklu (Př. 2) k Písním

\footnotetext{
7 MANN, op. cit., s. 12.

8 Ibid., s. 12-13. Překlad autora studie.

9 Ibid., s. $12-13$.

10 Lehmann uvádí název cyklu Fünfzehn Phantasiebilder zu Tonstücken (Ibid., s. 12). Z těchto 15 kreseb cyklu měl Max pro 1. a 2. vydání vybrat 13 a pro 3. vydání jen 12 .

11 Pro první vydání fotografoval vydavatel Gustav Jägermayer, pro třetí mnichovský fotograf Franz Bruckmann. V tomto vydání jsou listy označeny: Gab. Max fec. - Fr. Bruckmann phot.
} 
beze slov Felixe Mendelssohna-Bartholdyho v Shepherd Gallery v New Yorku. ${ }^{12}$ V prvním případě se jedná o kresbu tužkou stínovanou štětcem černě, šedě a s bílými akcenty, v druhém př́ipadě jsou kontury provedeny tuší a kresba je kolorována akvarelovými barvami; všechny kresby jsou samozřejmě reprodukovány černobíle. Vydání cyklu zaštítil vévoda Ernst von Coburg-Gotha, když přijal jeho dedikaci (,die Dedication dieses musikalisch-artistischen Prachtwerkes“") a umělci udělil zlatou medaili za umění a vědu. ${ }^{13}$

Svébytnou součástí díla je osmistránkový autorský výklad datovaný v Praze v červnu 1862. V úvodu Max objasnil svůj tvůrčí př́istup $\mathrm{k}$ hudební tematice. Vymezil se vůči obvyklým vizualizacím, kdy se jedná o pouhé zobrazení námětu (např. textu písně). Zdůraznil schopnost hudby dosáhnout svými vlastními pro-

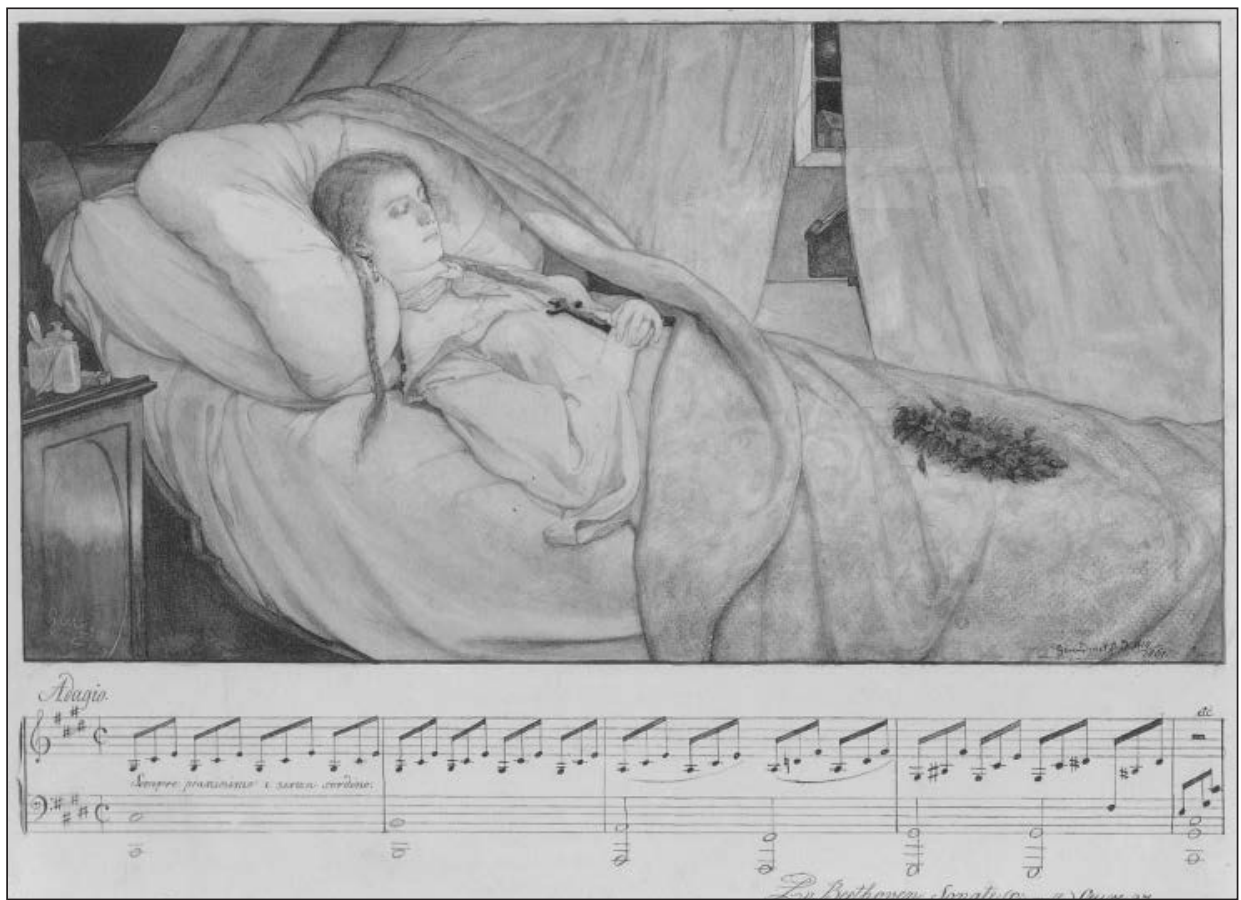

Př. 1 Gabriel von Max, Obrazové fantazie k hudebním skladbám, 3. list cyklu k Beethovenově klavírní Sonátě měsičního světla (opus 27), 1861, kresba tužkou a štětcem. Kunstforum, Ostdeutsche Galerie, Regensburg. Foto Wolfram Schmidt.

12 STILJANOV-NEDO, Ingrid et al. Von Chodowiecki bis zur Gegenwart. Eine Auswahl aus der Graphiksammlung. Regensburg: Museum Ostdeutsche Galerie, 1993, s. 44-45, rozměr kresby: $19 \times 35,2 \mathrm{~cm}$ (bez notace); Shepherd W \& K Galleries. European Paintings, Drawings and Scuplture [online]. [cit. 12. 9. 2013]. Dostupné z: $<$ http://www.shepherdgallery. com/view_image.html?image_no=419>, rozměr kresby: $28,7 \times 34,3 \mathrm{~cm}$ (včetně notace).

13 MAX, Gabriel. Erläuterungen zu den Phantasiebildern zu Tonstücken. Wien: Jägermayer \& Companie, 1862, s. 1; MANN, op. cit., s. 14. 


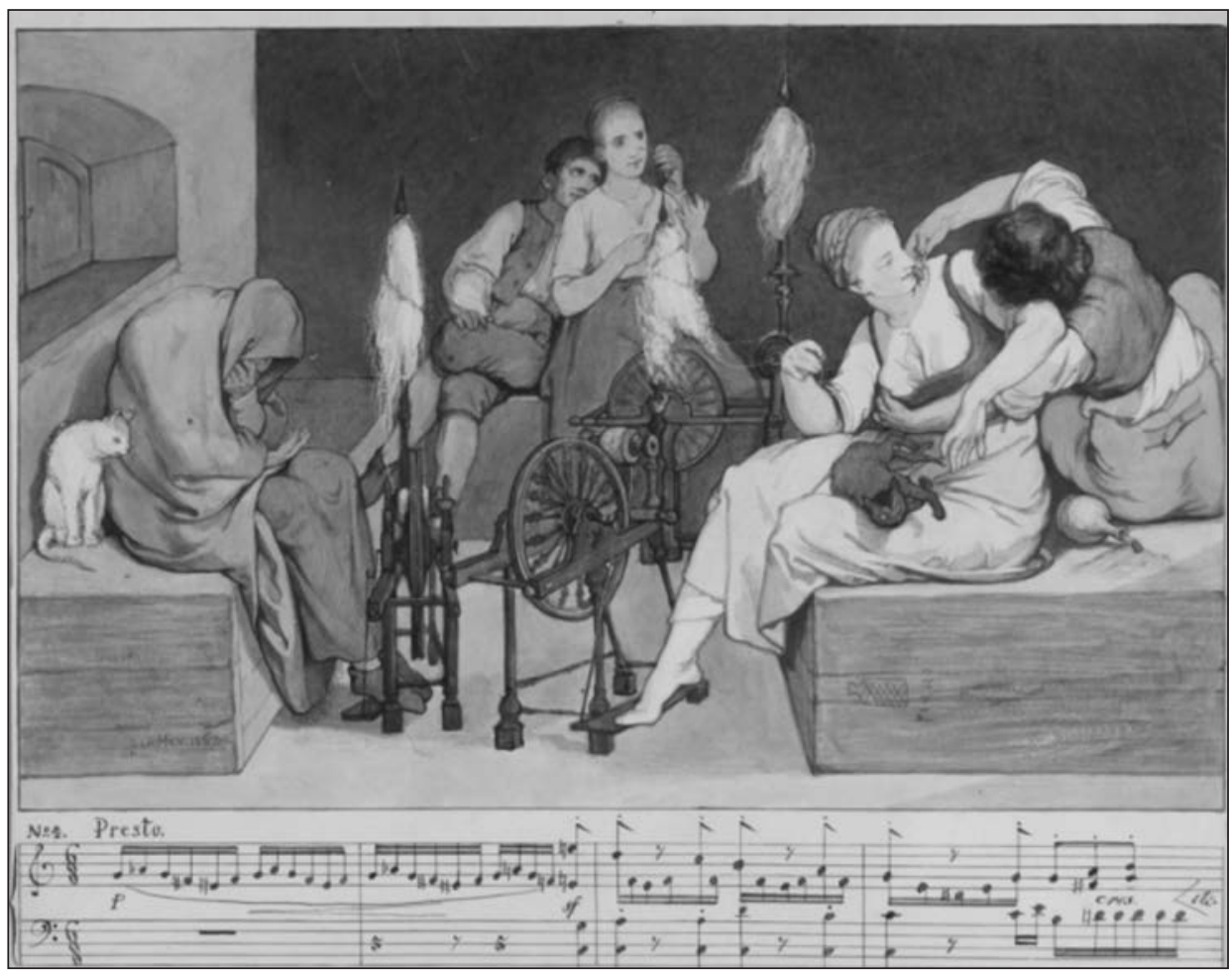

Př. 2 Gabriel von Max, Obrazové fantazie k hudebním skladbám, 5. list cyklu k Písním beze slov Felixe Mendelssohna-Bartholdyho k Písni tkalců (op. 67, č. 4), kresba tuší, kolorovaná akvareem. Shepherd Gallery, New York.

středky bezprostředně nálady, kterou líćí, přičemž u ní nehrozí, v tak velké míře jako u výtvarného umění, ,zkráceni estetického požitku nepovolanou myšlenkou či estetickým předsudkem". Max vysvětluje, že ve svých kreslírských kompozicích přistoupil k hudbě dvojím způsobem: 1) Skrze čistě subjektivní spojení hudebního a imaginativního vjemu, jež je založeno na jeho zkušenosti: „die Erfahrung, dass ein vor Jahren gehörtes und lieb gewonnenes Tonstück, in späteren Jahren wiedergehört, die ganze Stimmung und Situation, unter der man dasselbe zuerst liebgewonnen, auf merkwürdig lebhafte Weise illustrirt reproducirt." ${ }^{\text {"14 }}$ 2) Objektivnějším a všeobecnějším vyjádřením života mysli (Gemüthsleben) skrze hudbu, když výtvarná práce má vzbudit podobnou náladu jako hudební dílo, ovšem opět bez konkrétních obsahových odkazů, se snahou o propojení s jeho všeobecným charakterem.

Ač toto autorovo odlišení dvou tvůrčích prúístupů bývá chápáno jako hlavní klíč k pochopení celého cyklu, rozdíl mezi nimi není př́liš výrazný, a hlavně 
je vzdálen objektivitě. Zda si umělec spojil hudební a imaginativní vjem někdy dř́ve, nebo tak činí až při práci na svém díle, je pro diváka bez výkladu stě̌zí rozeznatelné a výsledek zůstává v obou př́padech autorsky subjektivní. Lze namítnout, že k objektivizaci umělcovy imaginace přispělo využití dobře známých motivů křest’anské ikonografie, ${ }^{15}$ odkazy na názvy skladeb, formální analogie mezi hudbou a kresbou; ty však nejsou vyhrazeny pouze pro druhý tvůrčí př́istup. Domníváme se, že lze najít ještě jinou důležitou distinkci, a sice mezi narativním, nebo synestetickým působením jednotlivých kreseb; uvažujeme tedy o dvou možnostech vizualizace hudby - její asociací bud's dramatickým dějem, nebo s nedramatickou scenérií, v níž se většinou odehrává hudební akce.

Autorský výklad pro nás zůstává zásadním, byt' ne jediným klíčem k pochopení díla. $V$ době jeho spesání převládal důraz na vnímání narativní složky výtvarných děl, což bylo typické pro výtvarnou kritiku v prostředí literátů. Podle Maxe je však čistá forma nadřazena literárnímu výkladu díla: „Selbst zu jener Musik, die ohne Rücksicht auf alle Schilderung und ohne Absicht auf Äusserungen des Gemüthslebens nur nach ihrem eigenen Baugesetze sich bildet und nur ihre ureigene Schönheit darrstellt, sind bildliche Compositonen möglich, deren Schönheit aber auch nur auf der acumetrischen Raumtheilung und der Harmonie der Linienbewegung beruhen muss. " ${ }^{16} \mathrm{Z}$ citovaného textu je patrné, že formální analogie mezi hudebním a kresebným dílem Max nacházel v proporcích a harmonii; nepochybně i proto nazýval své kresby kompozicemi. Čistou, instrumentální hudbu, která př́mo zasahuje mysl i city, Max nadřazoval jiným hudebním formám (na opačném pólu by bylo operní divadlo) a snažil se docílit podobného efektu výtvarnými prostředky. Zdá se, že jeho názor v průběhu let nedoznal zásadní změny, byt' ve svém malî́ském díle ztvárnil několik námětů z oper Richarda Wagnera; k nim se však stavěl nejinak než k čistě literárním námětům. Nejinspirativnějším hudebním skladatelem byl pro Maxe Ludwig van Beethoven, když s jeho klavírními sonátami spojil pět svých kreseb. Velký prostor mu věnoval také ve svém zápisníku z doby kolem roku 1860, tedy z času svých vídeňských studiî. ${ }^{17} \mathrm{Na}$ rozdíl od vytištěného autorského výkladu, kde skladatelé $\mathrm{W}$. A. Mozart a J. Haydn vůbec nejsou uvedeni, ve svých soukromých zápiscích se Max zaměřil na srovnání toho, jak na něj působí Beethovenovy skladby ve srovnání s tvorbou těchto jeho předchůdců. Dospěl k paradoxu: ač je Beethoven subjektivnější než Mozart, jeho hudba má určitější výraz než Mozartova a Haydnova. Podle Maxe Beethoven „kreslí určité situace“ a „ličí žretelně rozpoznatelné stavy duše“, čímž

15 Nejedná se o zcela volné asociace, nýbrž o tematizace zoufalství, smrti a zbožnosti s výraznými odkazy na křest’anskou ikonografii. GOTTDANG, Andrea. Beethoven im Malkasten. Beziehungen zwischen Landschaftsmalerei und Musik um 1850. In Musicologica astriaca, Bd. 25. Die Vorstellung von Musik in Malerei und Dichtung. Barbara Boisits - Cornelia Szabó Knotig (eds.). Österreichische Gesselschaft für Musikwissenschaft, Wien 2006, s. 33-53, zde s. 48.

16 Ibid., s. 2 .

17 GNM Norimberk, DKA, NL Max, I, B-211. 
„stupňuje instrumentálni hru“ $\mathrm{k}$ dříve nedosažené „určitosti výrazu“ ${ }^{18}$ Hudba, poezie a malî̌ství jsou pro Maxe spojenými uměními, proto se výslovně ohrazuje proti ,pedantickému předsudku“, jímž je snaha o vydělení maliŕšství z hudby; můžeme dodat, že toto rozdělení bylo estetickým požadavkem klasicistní teorie umění, hlásaným nejen na školách, ale zastávaným mimo jiné i vlivným Richardem Wagnerem. ${ }^{19}$ Maxův slovník je založen na spojitosti mezi uměními, což výmluvně dokládá jeho výrok: „Básník tónů sleduje svioj poetický námět, tím že nás vede $k$ velikému obrazu duše, bohatému na různé nálady.“

Srovnání tř́ zmíněných skladatelů Max ve svých poznámkách rozvíjel na více úrovních, od životopisných detailů až po celkový dojem z jejich tvorby. Jejich vztah ke společnosti popsal slovy: „Haydn uzavřenýv dětsky patriarchálních poměrech, Mozart v pestré rozmanitosti života, Beethoven osamélý vede do vnitřrního světa." Maxe zajímal také milostný život tohoto umělce; poznamenal si, že byl zamilován jen jednou, vášnivě, ale bez naplnění. ${ }^{20}$ Beethoven pro něj reprezentuje lásku k bližnímu, zato Mozart lásku pohlavní a Haydn kosmickou. Ač srovnáním s jinými Max dostatečně zdůraznil přednosti svého nejoblíbenějšího skladatele, ve zveřejněném výkladu se srovnání vyhnul, snad proto, že si byl vědom subjektivismu své argumentace a že se nechtěl dotknout četné obce Haydnových a Mozartových ctitelů.

\section{Kompozice}

Maxem užívaný pojem kompozice je pro tuto kapitolu skutečně výstižný, protože nás budou zajímat výtvarné i s nimi spojené hudební kompozice jeho cyklu. Zaměříme pozornost na jednotlivé kresby i na sestavu celku. Myšlenku, že v něm najdeme in nuce motivy autorových budoucích obrazů, ${ }^{21}$ konkretizujeme alespoň $\mathrm{v}$ těch př́ípadech, kdy analogie bude výrazná.

Titulní list cyklu (Př. 3) autor spojil s klavírní skladbou Franze Liszta dle Meyerbeerovy opery Le Prophète, a sice Illustrations du Prophète, Nr. 3. Prostá tklivá

18 Přepis tohoto pramene - viz Př́lohu. Obdobně uvažoval o Beethovenovi, o „vnitřním programu“ jeho symfonií, Gustav Mahler v dopisu Maxi Marschalkovi z 20. 3. 1896; viz WÜRTENBERGER, Franzsepp. Malerei und Musik. Die Geschichte des Verhaltens zweier Künste zueinander - dargestellt nach den Quellen im Zeitraum von Leonardo da Vinci bis John Cage. Frankfurt am Main: Peter Lang, 1979, s. 79.

Více mu ovšem záleželo na hudbě bez malîřských efektů. Viz GOTTDANG, Andrea. Vorbild Musik, op. cit., s. 247-248.

20 Není nám známo, ze kterého zdroje Max čerpal, ovšem k roku 1860 bylo k dispozici už několik umělcových životopisů. Představa romantické lásky, jež musí být jediná, je ovšem stylizovaná a biografické bádání ji vyvrací. Viz např. The Beethoven compendium. A guide to Beethoven's life and music. Barry Cooper (ed.). London: Thames \& Hudson, 1991, s. $106-108$.

21 Viz např. RICHTER, op. cit., s. 69; Některé konkrétní analogie: MÜLLER, Rudolf. Künstler der Neuzeit Böhmens. Biographische Studien. XIII. Gabriel Max. Mittheilungen des Vereines für Geschichte der Deutschen in Böhmen, 1889, roč. 27, s. 289-326, zde s. 297-298. 
melodie: $\mathrm{v}$ obou řádcích $\mathrm{z}$ úvodu partitury se motiv opakuje $\mathrm{v}$ echu. Libovůli subjektivity můžeme spatřovat už v tom, že Max si nevybral ke zobrazení figuru u klavíru, nýbrž houslistku. Podle autorského výkladu ${ }^{22}$ jde o chudé slovanské děvče, alegorii malířství a hudby, žebračku, která odložila štětec a paletu (do uzlíku po levici) a vydala se do cizí země vyžebrat si obživu hraním na housle. Při své cestě spočinula na louce: „Auf einer Weide ruht es [das Mädchen, pozn. aut.] aus und lauscht träumerisch mit geschlossenen Augen dem Echo seiner Lieder, die es in die Nacht hinaus erklingen lässt. " ${ }^{23}$ Titulní list je chápán jako alegorický programový manifest celého cyklu; tematizován je vztah malířství a hudby, přičemž je nadřazeno emotivnější umění, tedy hudba. Dále je důležité, že se jedná o nokturno, noční scenérii ozářenou měsícem, evokující snění; kresby svého cyklu autor chápe jako „sny vzbuzené zvukem“. ${ }^{24} \mathrm{Z}$ výtvarného hlediska se u titulní kresby nabízí zatím nepovšimnutá paralela s dílem Josefa Mánesa, s jeho lyrickými typy slovanských žen, jež Max patrně znal z Prahy; k tomu by mohla směřovat již citovaná zmínka, že se jedná o slovanské děvče. Jako nejbližší analogie k Maxově dívce-umělkyni se u Mánesa jeví ženská figura z litografie Domov, rovněž sedící a hrající na housle; tato litografie $\mathrm{z}$ roku 1855 byla výroční prémií Jednoty umělců výtvarných, a tudíž se na veřejnosti rychle rozš́iřila. ${ }^{25}$ Později se Max k námětu chudé opuštěné dívky ve volné krajině vrátil v obraze Sirotek ${ }^{26}$

Druhý list cyklu (původně třetí) představuje mrtvou dívku na lůžku, rovněž v noci za měsíčního světla. Tento přitažlivý motiv Max později obměnil v obrazech Dceruška hostinské či Julie Kapuletová o svatebni noci (dvě verze). ${ }^{27}$ $\mathrm{S}$ kresbou dívky na úmrtním loži (Př. 1) je spojena Beethovenova nejznámější Klavirní sonáta cis moll, opus 27, pro níž se záhy vžil skladatelem nezamýšlený název Sonáta měsičního světla; pro Maxe zjevně inspirativní, nebot' pro iluzivní osvětlení pokoje měsíčním světlem zvolil reflektorový způsob. Třetí (původně druhá) kresba se vztahuje k písni Die schönsten Augen dnes málo známého italského skladatele Giorgia Stigelliho. ${ }^{28}$ Tady Max ve svém „playlistu“ udělal výjimku, jednak v tom, že zvolil jiného než německého nebo rakouského skladatele, a jednak v tom, že si vybral píseň, ač vesměs preferoval klavírní hudbu. Diváka, který se „zaposlouchá“ do jeho hudební scény, však asi překvapí ironií; v př́ímé konfrontaci s názvem písně totiž nakreslil orchestr slepců. Údajně

22 Autorský výklad: v tomto i dalších př́ípadech viz MAX, Gabriel. Erläuterungen zu den Phantasiebildern zu Tonstücken, op. cit.

23 Ibid., s. 3.

24 „Es sind eben vom Schalle geweckte Träume.“ Ibid., s. 2.

25 Viz REITHAROVÁ, Eva. Josef Mánes. Odkaz maliřru Mánesovy rodiny. Praha: Eminent Patrik Šimon, 2005.

26 Nyní jsou k dispozici jen přípravné kresby. Viz Gabriel von Max (1840-1915), op. cit., s. 160.

27 Viz Ibid., výběrový soupis Maxova díla, č. XXVIII, XVII-XVIII, s. 323, 321, Shakespearova hrdinka Julie je ovšem jen zdánlivě mrtvá. Viz též BRONFEN, Elisabeth. Over her death body. Death, feminity and the aesthetics. Manchester: Manchester University Press, 1992.

28 Mezi léty 1840-1949 byla partitura této písně vydána čtrnáctkrát v šesti jazycích. Viz: $<$ http://www.worldcat.org/identities/lccn-n89-633212> [cit. 11. 9. 2013]. 


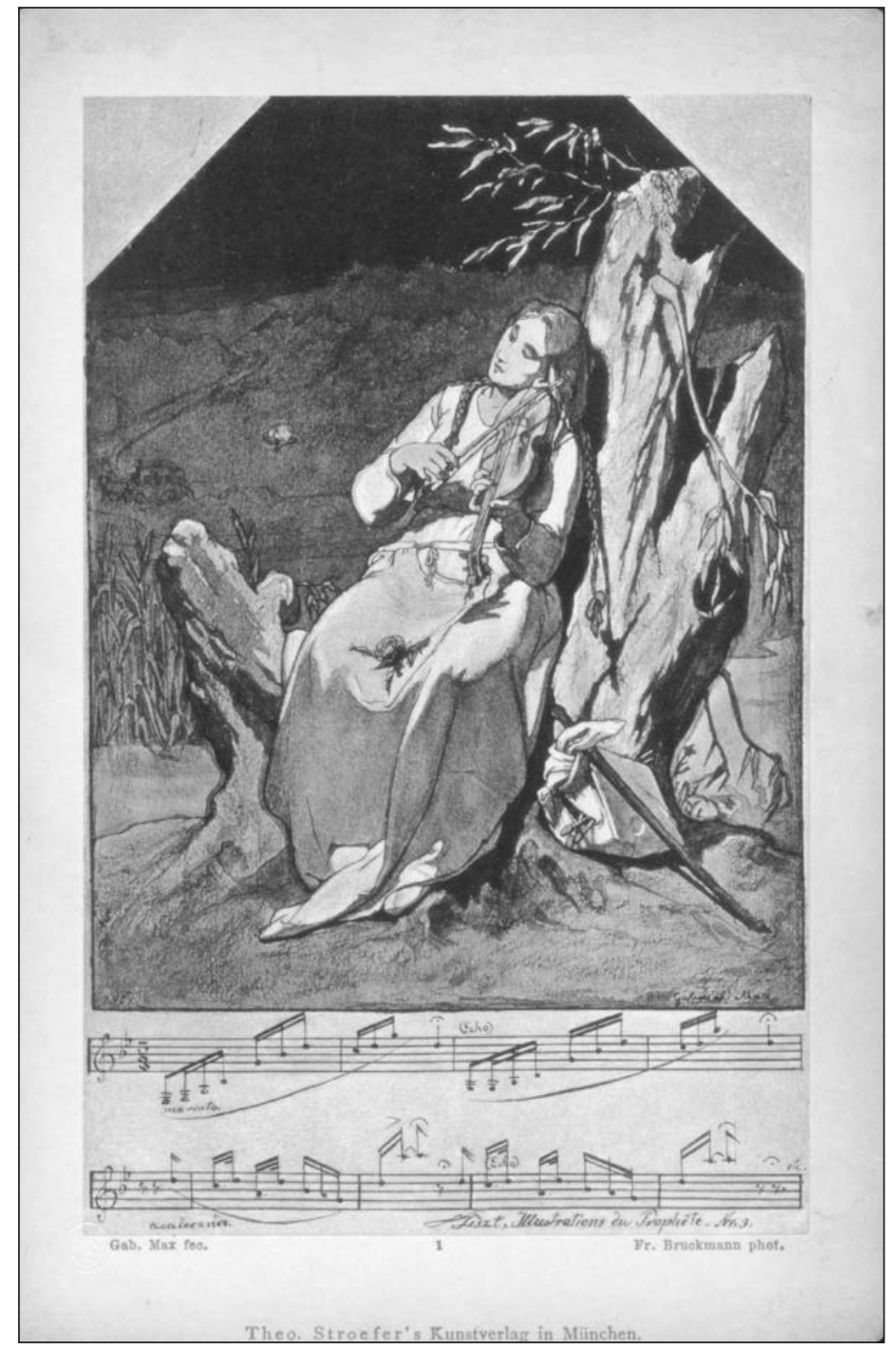

Př. 3 Gabriel von Max, Obrazové fantazie k hudebním skladbám, titulní list cyklu ke klavírní skladbě Illustrations du Prophète, Nr. 3 Franze Liszta, 1861. Repro dle 3. vydání, 1885. Foto GNM Norimberk.

v Praze v době jeho mládí takovýto soubor vystupoval a existoval ještě v době vydání Lehmannovy monografie. ${ }^{29}$ Také jeho učitel hudby Josef Proksch byl slepý. O tomto motivu lze uvažovat ještě jinak: niterné prožívání hudby odkazuje na jedno z pozdějších symbolistických topoi zavřených očí. ${ }^{30}$ Maxovo zařazení

30 Viz WITTLICH, Petr. Closed Eyes. Symbolism and new kapes of suffering. In Lost Paradi- 
mezi presymbolisty má tedy své oprávnění, ovšem i z jiných důvodů. ${ }^{31}$ Následuje čtvrtá kresba (původně jedenáctá), jediné krajinářské dílo celého cyklu, jež se připojuje $\mathrm{k}$ náladovým, nedramatickým kompozicím, dokonce i s kvazi hudebním motivem zpívajícího ptáka, který je v zimní scenérii předzvěstí jara. K zimní krajině se už svým názvem pojí skladba Roberta Schumanna Klavierstücke für die Jugend, Winterzeit, opus 68.

Interiérová figurální scéna s tkadlenami a jejich mužskými protějšky, $\mathrm{v}$ pořadí pátá (původně osmá, Př. 2), má jako svůj hudební korelát klavírní skladbu Felixe Mendelssohna-Bartholdyho Spinnerlied z cyklu Lieder ohne Worte, opus 67, č. 4. V doprovodném textu Max evokuje dva zvukové vjemy ,,in wirrer Melodie“: hučení kolovratů a zvuk Mendelsohnovy skladby, jež oba znějí v uších spící stařeny. ${ }^{32}$ Pozorný divák může objevit malou narážku na připojenou skladbu: na bedně vpravo nápis PIANO (kromě kresby lahve a lodě). Šestý list cyklu (Př. 4) Max věnoval svým prátelům, ${ }^{33}$ zřejmě těm, kteří s ním sdíleli zájem o přírodní vědy, nebot' je na něm vyobrazen Faust ve své pracovně; měsíční svit jí dodává př́ízračný ráz, což podtrhují v komentáři citované dva verše $\mathrm{J}$. W. Goetha: „O, säh st $d u$, voller Mondenschein, / Zum letzten Mal uf meine Pein." Další, jako motto citované verše z básně Fragen Heinricha Heineho odkazují na prastarou záhadu člověka a podle Maxe může totéž jako ony říci tomu, kdo př́isluší k modernímu faustovskému směru, adagio 2 . věty připojené Beethovenovy sonáty $B$ dur, opus 22 , stejně jako menuetto a rondo její 3. a 4. věty. ${ }^{34} \mathrm{Na}$ bádání o záhadě člověka na kresbě odkazují stojící kostra, ležící mrtvola pod plachtou, mumie zavěšená na stěně aj. Že se za moderního Fausta považoval sám umělec, nadšený amatérský př́ŕrodovědec, je už dostatečně známo. Kresba obsahuje nejvíce odkazů na jeho budoucí díla: od ilustrací a obrazů k Faustovi, přes obraz Anatom, až po tzv. opičí žánry.

Následují dvě hřbitovní scény mrtvých vstávajících z hrobů. Inspirace pro morbidní tématiku byla hledána u Alfreda Rethela, a pokud jde o patetická gesta, je patrný vliv Maxem studovaného Wilhelma von Kaulbacha. ${ }^{35}$ Sedmý list jakožto eschatologický původně celý cyklus ukončoval, hudební „doprovod“ tak gradoval Beethovenovou Sonate pathétique, opus 13. Na zadní stranu reprodukce si Max tužkou poznamenal svůj věk v době vzniku díla: „22 Jahre“. À tergo osmého listu (původně desátého, Př. 5) zanesl dodatečnou vzpomínku z Vídně, která pro něj byla oním prvním emocionálním a imaginativním popudem, propojeným

se. Symbolist Europe. Jean Clair (ed.). Katalog výstavy. Montral: The Montreal Museum of Fine Arts, 1995, s. 235-241.

31 Tohoto pojmu začal užívat historik umění Horst Ludwig, např. v katalogu výstavy Musea Villa Stuck viz Secession 1892-1914. Die Münchner Secession 1862-1914. Michael Buhrs (ed.). München: Museum Villa Stuck, 2008.

32 MAX, Gabriel. Erläuterungen zu den Phantasiebildern zu Tonstücken, op. cit., s. 6.

33 Značen: Gab. Max / Gewidmetseinen / Freunden / 1862.

34 MAX, Gabriel. Erläuterungen zu den Phantasiebildern zu Tonstücken, op. cit., s. 5.

35 Kresby podle Kaulbacha: viz Maxův skicář ve sbírce mnichovské Städtische Galerie im Lenbachhaus und Kunstbau. 


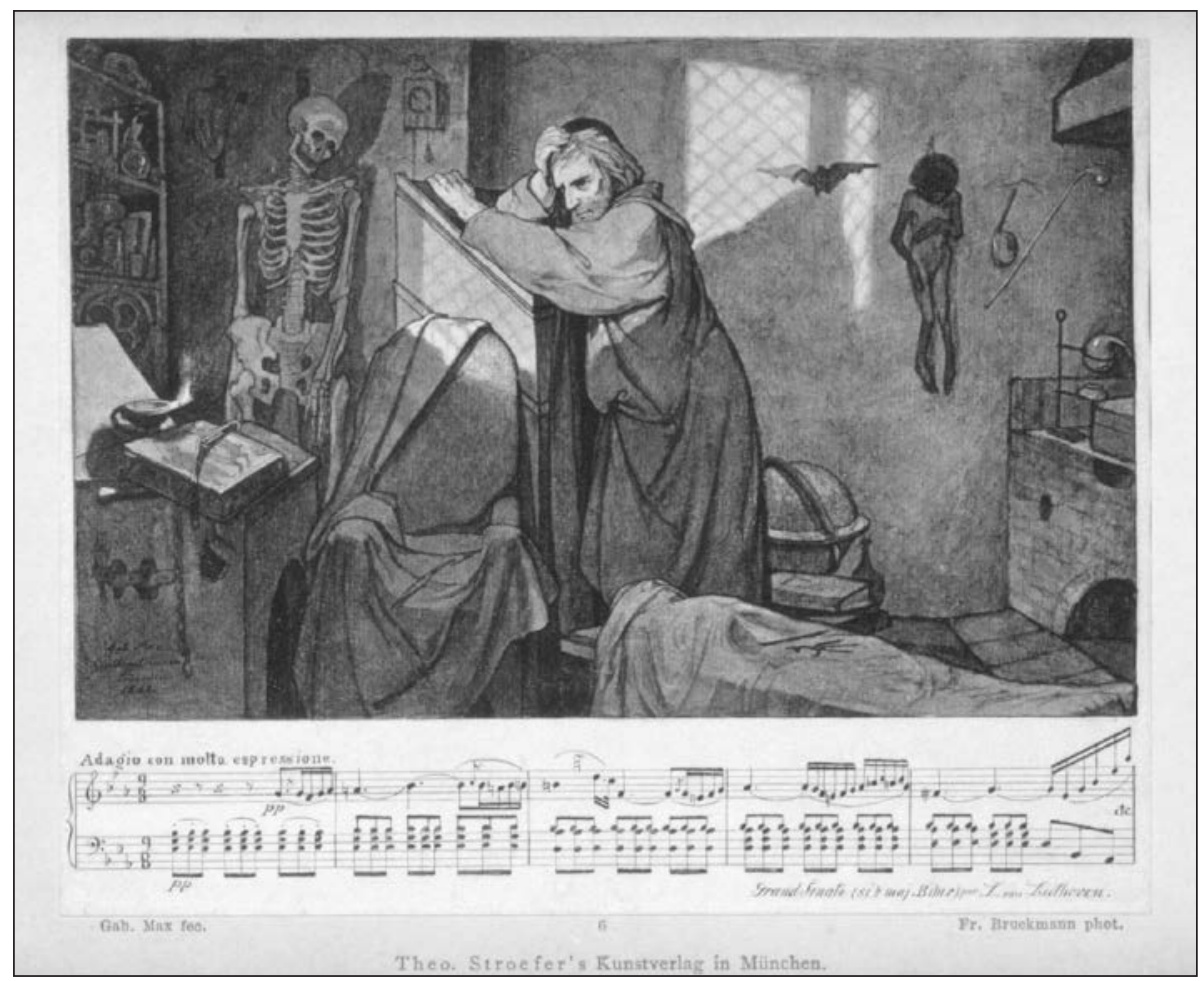

Př. 4 Gabriel von Max, Obrazové fantazie k hudebním skladbám, 6. list cyklu k Beethovenově sonátě B dur (opus 22), 1862, Repro dle 3. vydání, 1885. Foto GNM Norimberk.

s hudbou Felixe Mendelssohna-Bartholdyho: „Weringer [Währinger, pozn. aut.] Friedhof-August-9 Uhr-Zerdicht Mond und Dämmerung - heißer, trockener Tag - Staubluft - [Ich] komm[e] erschüttert aus dem Friedhof - Grab: Schubert: in die Hände gefallen - dankbar lese ich Beethoven, erschüttert stört mich Glokkengeläute - Hundegebell - Friedhof geschlossen - [ich] trete vor das Gitter hinaus, da jagt der Tod mit seinen Fanen [Fahnen, pozn.aut.] seine Errungenschaften heim in Staub, Zwielicht und Mondlicht - es war ein Metzgerwagen." ${ }^{\text {"36 }}$ Podvečer na hřbitově líčí Max také ve vydaném autorském výkladu, kde pracuje s literární stylizací cílící ke zvukovým evokacím: „[...] es poltert das Pferd, das Armensünder-Glöcklein wimmert, darunter mischt sich das Winseln und Heulen überfahrener Hunde, die Kirchhoftür steht offen, bald wird der Spuk vorbei sein, das Thor sich schließen - lautlose Stille - nur der Fluss rauscht fort dem Meere entgegen, wie die Jahre eines Menschenlebens. " ${ }^{37} \mathrm{Nad}$ těmito doprovodnými

37 MAX, Gabriel. Erläuterungen zu den Phantasiebildern zu Tonstücken, op. cit., s. 7. Motto je citací z básně Nikolase Lenaua. 


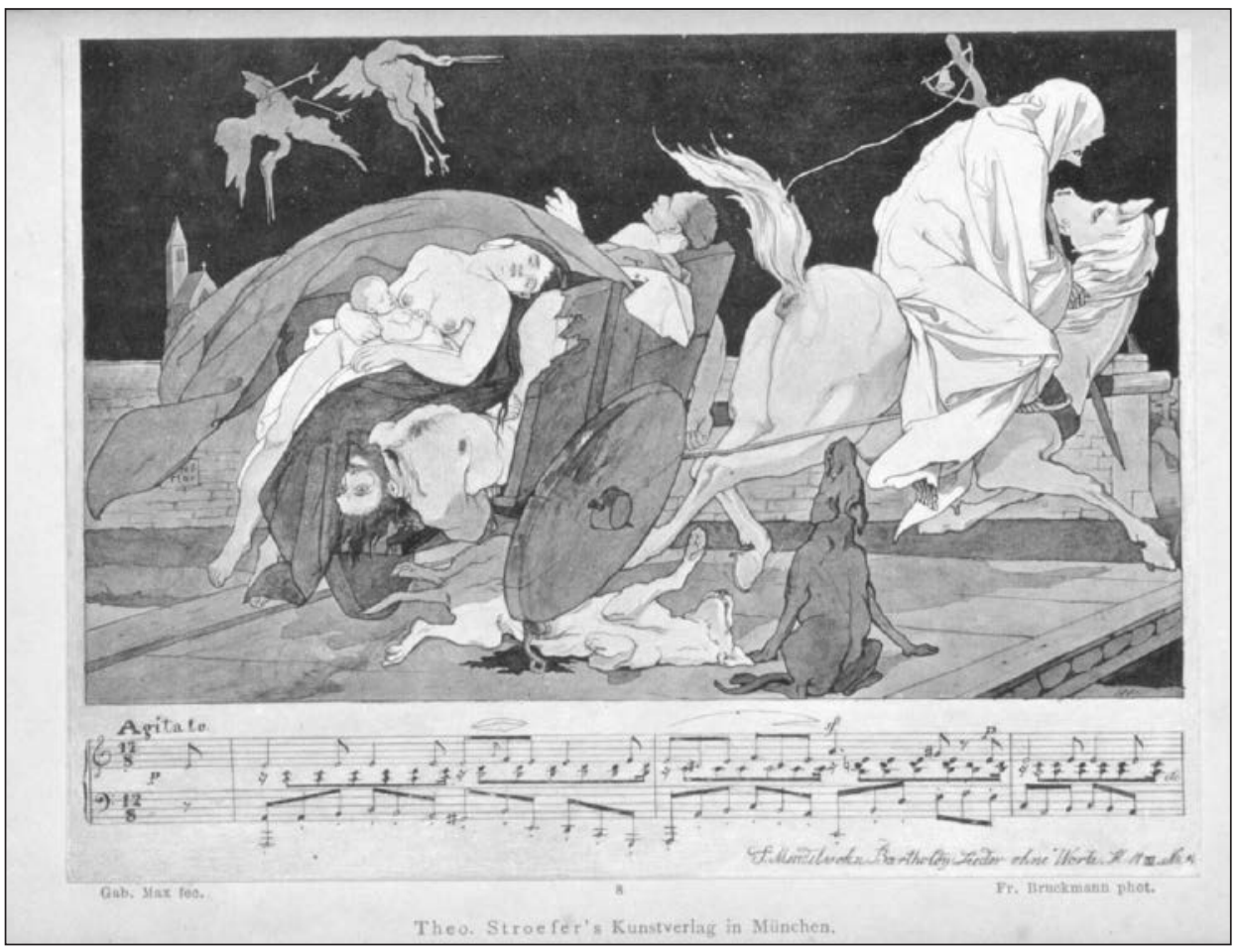

Př. 5 Gabriel von Max, Obrazové fantazie k hudebním skladbám, 8. list cyklu k Mendelssohnovu agitatu a moll z cyklu Lieder ohne Wörte, 1862. Repro dle 3. vydání, 1885.

Foto GNM Norimberk.

zvuky má divák-čtenář-posluchač jasně vnímat zvuk klavíru, když zaznívá Mendelssohnovo agitato a moll z cyklu Lieder ohne Wörte.

V 9.-11. listu cyklu Max ztvárnil pašijovou tématiku: Kristus potkává jeruzalémské ženy (námět VIII. zastavení Křížové cesty) za „hudebního doprovodu“ oratoria Kristus Mendelssohna-Bartholdyho; Kristus na křiži umirá (XII. zastavení) za zvuků Beethovenovy první sonáty, Appasionaty; Panna Maria Bolestná se sv. Maři Magdalenou a sv. Veronikou (obměna motivů VI. a XIII. zastavení) spojená s Beethovenovou Sonátou G dur, opus 14. Max jako vždy usiloval o ikonografické inovace, byt' $v$ tomto př́ípadě méně výrazné, a přitom vystupňoval dramatičnost pašijových výjevů odehrávajících se v měsíčním světle. Desátý (původně dvanáctý) list s námětem Ukřižování věnoval své zbožné matce; ${ }^{38}$ pouze tento a šestý list jsou opatřeny dedikacemi. Jeho spojení s Appasionatou autor zdůvodnil vážností skladby, a pritom citoval úryvky z popisu Kristova ukřižování vizionářky Anny Kateřiny Emmerichové; ${ }^{39}$ její podobu ztvárnil v 80 . letech

39 MAX, Gabriel. Erläuterungen zu den Phantasiebildern zu Tonstücken, op. cit., s. 7. 
na známém obrazu z Nové pinakotéky v Mnichově. V témže decenniu se maliř vrátil k motivu Ukřižování obrazem Dokonáno jest! Jedenáctý (původně čtvrtý) list s trojicí žen pod křížem se vyznačuje monumentalizujícím, hieratickým podáním, stupňujícím principy nazarénského umění, čímž se liší od modu živého vyprávění ostatních kreseb.

V konečné úpravě své výtvarně-hudební kompozice se Max přiklonil ke zklidnění, když diváka přivádí ke zbožné meditaci v klášterní kapli řeholních sester ve 14. století (Př. 6). Na své kresbě, již doprovází začátek chorální partitury a jíž se vrací do Prahy, ${ }^{40}$ ukazuje zpívající sestry při večerní pobožnosti. Výjev je opět potemnělý, dle autorova výkladu tu svítí věčné světlo a zní večerní zvon. Také tato kresba předznamenala jednu tématickou oblast Maxova malířského díla: obrazy jeptišek, reprezentované díly Jeptiška v klášterni zahradě, Nalezenec atd. ${ }^{41}$ Ve 3 . vydání svého

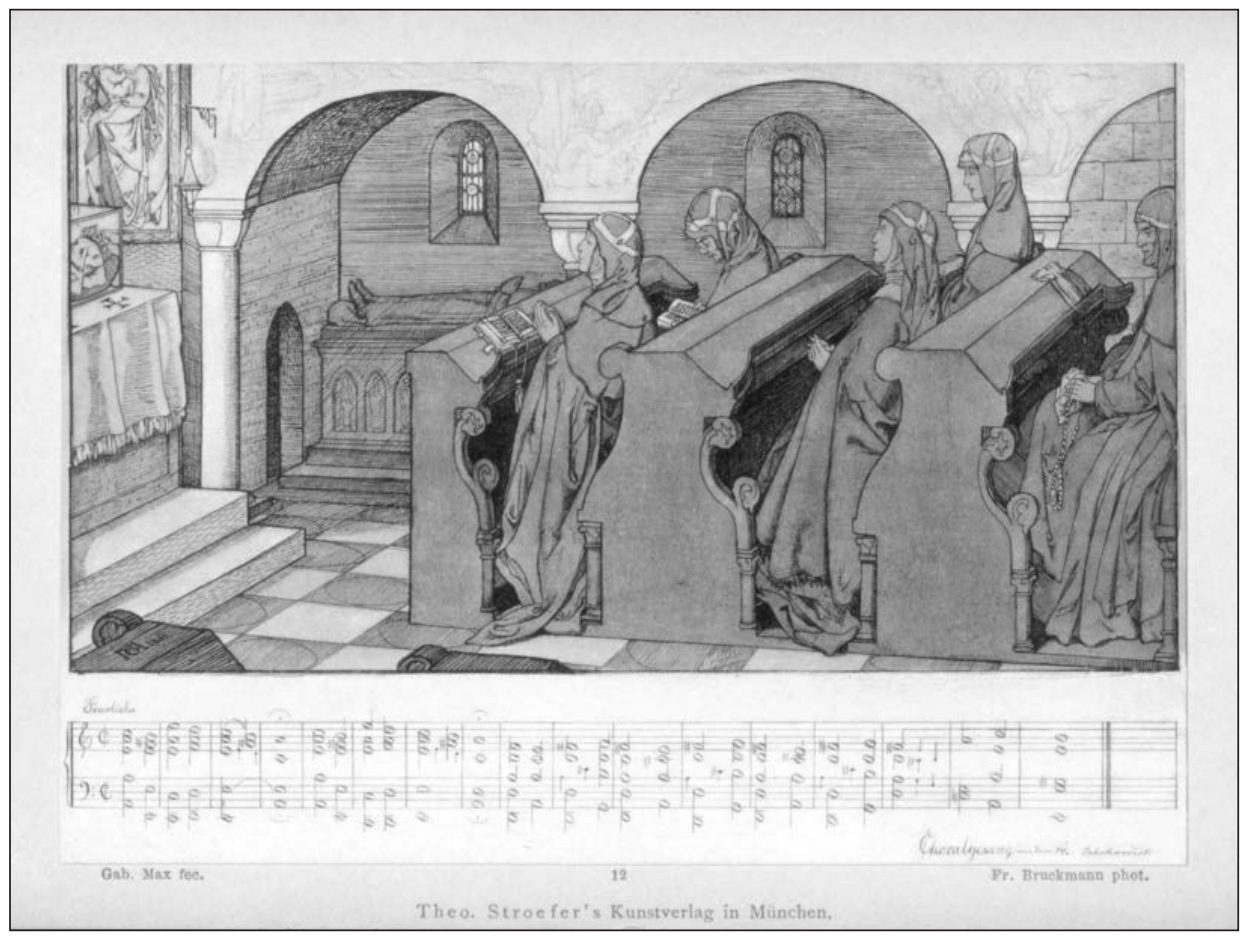

Př. 6 Gabriel von Max, Obrazové fantazie k hudebním skladbám, závěrečný list cyklu k chorálnímu zpěvu, 1861, Repro dle 3. vydání, 1885. Foto GNM Norimberk.

$40 \quad$ Na začátku svatováclavský chorál, $\mathrm{v}$ druhé části s motivem písně Hospodine, pomiluj ny. Za upřesnění děkuji dr. Vladimíru Maňasovi a dr. Tomáši Slavickému. Ten také upozornil na skutečnost, že Maxem znázorněná kaple odpovídá architektuře krypty baziliky sv. Jiř́i na Pražském hradě.

41 Gabriel von Max (1840-1915), op. cit., s. 162-168. 
cyklu Max vypustil kresbu matky s mrtvým dítětem, již spojil se skladbou Russische Melodien Leopolda Meyera; snad proto, že vyznívala př́liš melodramaticky. Nevíme, proč bylo u 3. vydání pozměněno řazení scén; asi největší změnou byl přesun dvou eschatologických scén do střední části cyklu, zatímco původně tvořily jeho finále (10. a 13. list), přičemž mezi ně byla vložena lyrická zimní scéna (k hudbě Schumanna) a scéna Ukřižování s Beethovenovou Appasionatou.

\section{Závěr}

Ojedinělá forma spojení výtvarného umění, hudby a literatury, k níž Gabriel von Max dospěl ve svém raném cyklu, vyvolává další otázky. Na jedné straně Max preferoval mezi uměními to nejabstraktnější, a zároveň nejemotivnější, tedy hudbu; snad k tomu přispěl i jeho oblíbený filosof Arthur Schopenhauer, který ji takto vyzdvihl ve svém hlavním spisu Svět jako viole a představa.$^{42} \mathrm{Jak}$ je patrné $\mathrm{z}$ „dramaturgie“ jeho cyklu, Max upřednostňoval instrumentální hudbu; k tomu se vyjádřil i ve svých poznámkách z roku 1895, v nichž také odmítl programovou hudbu jako omezující posluchače. ${ }^{43} \mathrm{Na}$ druhé straně však jeho poměrně obsáhlý slovní doprovod $\mathrm{k}$ výtvarnému cyklu směřuje $\mathrm{k}$ programovému vnímání díla. Třetí vydání již zřejmě autorský výklad neobsahovalo, soudíce dle toho, že $\mathrm{v}$ umělcově pozůstalosti je k němu připojen vytištěný text $\mathrm{k} 1$. vydání ${ }^{44}$ Sám autor byl, zdá se, na pochybách, zda výklad dílu prospívá či škodí. Pro interpreta je ovšem př́nosný, zvláště s ohledem na otázku po spojení kreseb a skladeb. Výklad však do vnímání cyklu vnáší ještě další dimenzi, a to literární; nejen dík tomu, že jsou citováni básníci Goethe, Lenau či Heine, ale i dík poetickému ladění Maxova textu, jenž místy evokuje zvukové vjemy.

Ve dvou př́padech můžeme z osobních poznámek, sahajících nad rámec literárně stylizovaného autorského výkladu, vysledovat, od jaké vzpomínky, spojené $\mathrm{s}$ hudebním vjemem, je odvozován námět kresby. ${ }^{45}$ Víme tedy, že 2 . a 8 . list cyklu patří $\mathrm{k}$ těm, $\mathrm{u}$ nichž autor vycházel čistě ze svého subjektivního prožitku. Naopak u 5. listu byla, zdá se, na počátku Mendelssohnova Píseň tkalcůu, k níž autor vytvořil výtvarný ekvivalent s určitými objektivizujícími prvky: tak vírivá melodie skladby našla výraz v pohybu pravé skupiny figur, a hlavně - zobrazené figury tkadlen odpovídají názvu skladby; tady se Max již povážlivě přiblížil tomu, co ve svém výkladu označil jako jednoduchou vizualizaci textu (jenž se tu však, nutno dodat, omezuje pouze na název). Sám autor si, jak už bylo uvedeno, více

\footnotetext{
42 Není však jasné, zda jej Max už v této době znal. Viz RICHTER, op. cit., s. 83.

43 Viz GOTTDANG, Andrea. „Vom Schalle geweckte Träume.“ Gabriel von Max und die Musik, op. cit., s. 56.

44 GNM Norimberk, DKA, NL Max, I,B-407. Výtisky díla jsou obtížně dostupné, ani M. M. Richter, ani A. Gottdang neměla k dispozici jiné vydání než tohle.

45 Vzpomínka k 8. listu cyklu je citována výše v textu, vzpomínka k 2. listu, z Maxovy cesty k Severnímu moři, viz GOTTDANG, Andrea. „Vom Schalle geweckte Träume.“ Gabriel von Max und die Musik, op. cit., s. 57.
} 


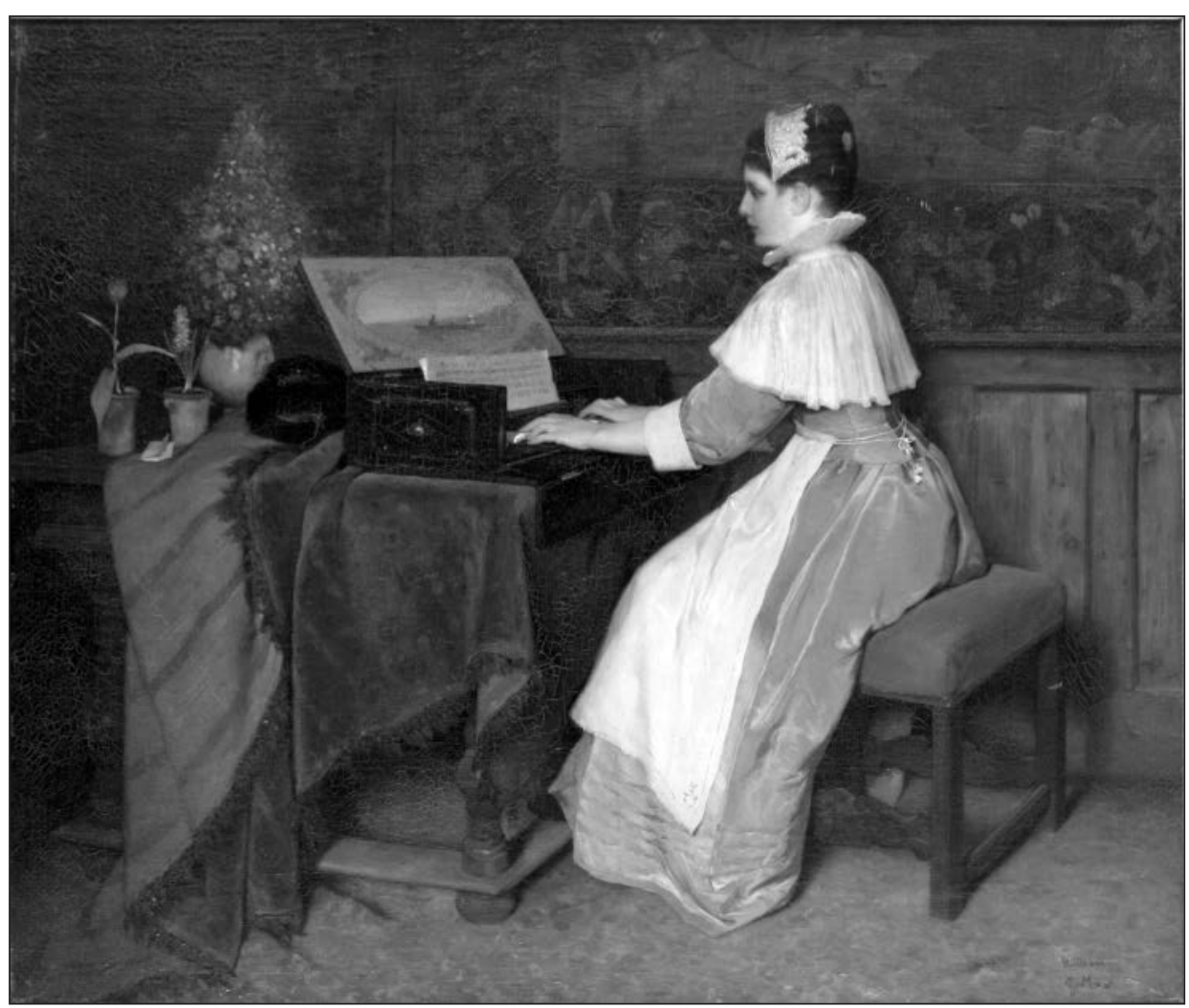

Př. 7 Gabriel von Max, Zátiší (Dívka u spinetu), 1871, olej na plátně. Oblastní galerie, Liberec. Foto Jaroslav Trojan.

než syžetových cenil formálních analogií mezi hudbou a kresbou; při spojení obou hledisek můžeme jeho kompozice rozdělit na dramatické a lyricko-meditativní. Ty druhé, do nichž spadají mimo jiné všechny vizualizace hudebních produkcí, jasně převažují, zatímco výrazně dramatické, v patetickém duchu Kaulbachova umění, jsou jen dva listy s eschatologickými náměty. Dva pašijové náměty odpovídající VIII. a XII. zastavení Kř́žové cesty stojí na pomezí mezi těmito dvěma prrístupy. Dramatické scény jsou vystavěny na kompozičních diagonálách, ostrých úhlech a patetických gestech figur, zatímco lyricko-meditativní scény mají bud' ortogonální kompozici, někdy i symetrickou, nebo jsou založeny na nehluboké prostorové diagonále, a také na měkce splývavých liniích.

Gabriel Max získal hudební vzdělání a průpravu ve hře na klavír v Praze u Josefa Proksche (k jehož žákům patřil i Bedřich Smetana) a hudba jej po celý život přitahovala, což je patrné i v tematickém spektru jeho obrazů, v němž jsou zastoupeny lyrické žánrové obrazy jako Adagio nebo Zátiši (k nim najdeme dobové analogie u Arnolda Böcklina a Anselma Feuerbacha), dále obrazy na náměty z Tannhäusera 
a jiných Wagnerových oper, různá zpodobení sv. Cecílie atd. ${ }^{46}$ Malír̆i se dařilo dosahovat efektu synéstezie, tj. skrze zrakový vjem zasáhnout i sluch a ostatní smysly, už jen výjimečně se však přitom odvolával na konkrétní skladby jako ve svém raném cyklu. K výjimkám patří obraz Zátiší, který Max namaloval v roce 1871 a do své sbírky jej získal baron Heinrich von Liebig v Liberci (Př. 7). Malír si rád pohrával s názvy obrazů, takže tu ve skutečnosti nejde o zátiší, nýbrž o figuru v interiéru, jak to vysvětluje druhotný podtitul (Dívka u spinetu). Pro rozluštění syžetu díla je důležité si povšimnout, že dívka má před sebou partituru Mozartovy písně Přijd' již, ó věčný máji (slova Ch. A. Overbeck). ${ }^{47}$

Hudební tematika je zastoupena také u Maxových obrazů opic, tedy u jeho tzv. opičích žánrů. Malbu opice hrající na klavír nazval Písně beze slov (P̌r. 8), ${ }^{48}$ nedomníváme se však, že by to mělo skutečnou vazbu na Mendelssohnův cyklus, asi je tím jen naznačeno, že hraje „němá tváŕc“. Překvapivou pointu má Maxův velmi populární obraz Věneček (Opice jako kritici uměni) z roku 1889 ze sbírky Nové pinakotéky v Mnichově: zviŕata pozorují obraz, z něhož divák vidí jen zadní stranu a na ní nalepený štítek označující jeho námět - Tristan a Isolda. Vzhledem $\mathrm{k}$ tomu, že sám Max namaloval obraz s tímto wagnerovským syžetem v roce 1868, zdá se, že v roce 1889 nebyl prost sebeironie. ${ }^{49}$ Jeho velmi pozdním dílem je obraz Opice u klavíru z doby po roce 1905 (Př. 9); datování obrazu vyplývá z detailního „čtení “ plátna - namalovaná samice makaka totiž sedí na partituře operety Franze Lehára Veselá vdova, jejíž premiéra $\mathrm{v}$ Theater an der Wien se konala 28. prosince $1905 .^{50}$ Výběr partitury má zvíře charakterizovat jako rozverné, podobně jako láhev a převržená číše s vínem.

Vrátíme-li se k Maxovu ranému cyklu z let 1861-1862, těžko pro něj v jeho době hledáme analogie; $\mathrm{v}$ tom se shodují obě citované interpretky, přičemž $\mathrm{M}$. M. Richter považuje za obdobné dílo, které nechce pouze vizuálně představit hudbu, ale také vyvolat podobnou náladu jako konkrétní uvedená skladba, až grafický cyklus lipského umělce Maxe Klingera Brahms Phantasie z roku $1894 .{ }^{51}$ Na druhé straně je zřejmé, že Max navázal na romantickou tradici překračování hranic mezi uměními, na koncepty hudebního maliřrství, či souběžného vnímání výtvarného a hudebního díla, jak je reprezentují např. Phillip Otto Runge, Caspar David Friedrich či Moritz von Schwindt. ${ }^{52}$ Pro Maxem užívanou hudebně-vý-

\footnotetext{
$46 \quad$ Ibid.

47 Gabriel von Max (1840-1915), op. cit., s. 151-153.

48 Obraz z doby po r. 1900 ve sbírce Jacka Daultona v Los Altos Hills, Kalifornie, USA. Reprodukce, ibid., s. 207.

49 FILIP, Aleš - MUSIL, Roman. Ein wahrer Homunkulus in der Tierwelt. Gabriel von Max' Affenbilder. Umění, 2010, roč. 58, s. 294-311.

50 Ibid., s. 298.

51 RICHTER, c.d., s. 81-82.

52 GOTTDANG, Vorbild Musik, c.d., pas. - VERGO, Peter. Music and the visual arts. In The Romantic spirit in German art 1790-1990. Keith Hartley (ed.). London: Thames \& Hudson, 1994, s. 131-137.
} 


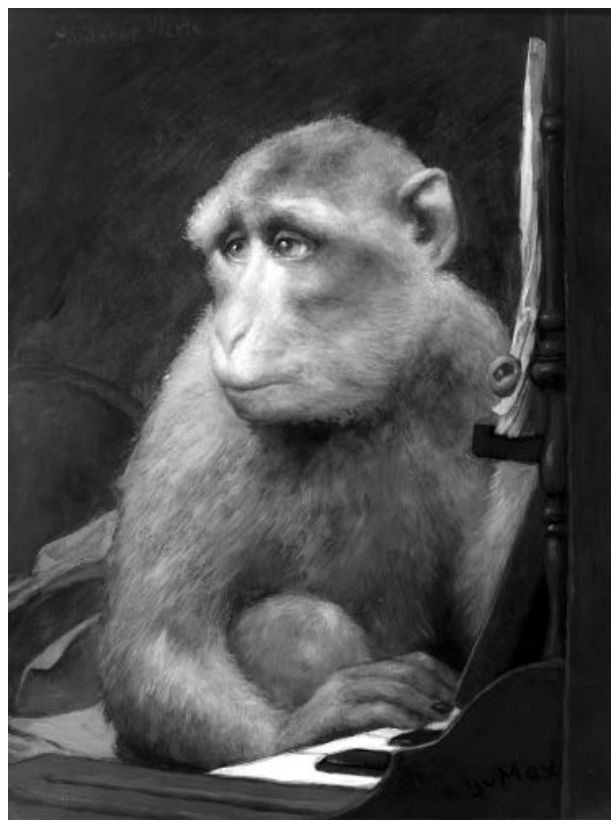

Př. 8 Gabriel von Max, Písně beze slov, po 1900, olej na dřevě. Sbírka Jacka Daultona, Los Altos Hills, Kalifornie, USA. Foto Don Tuttle.

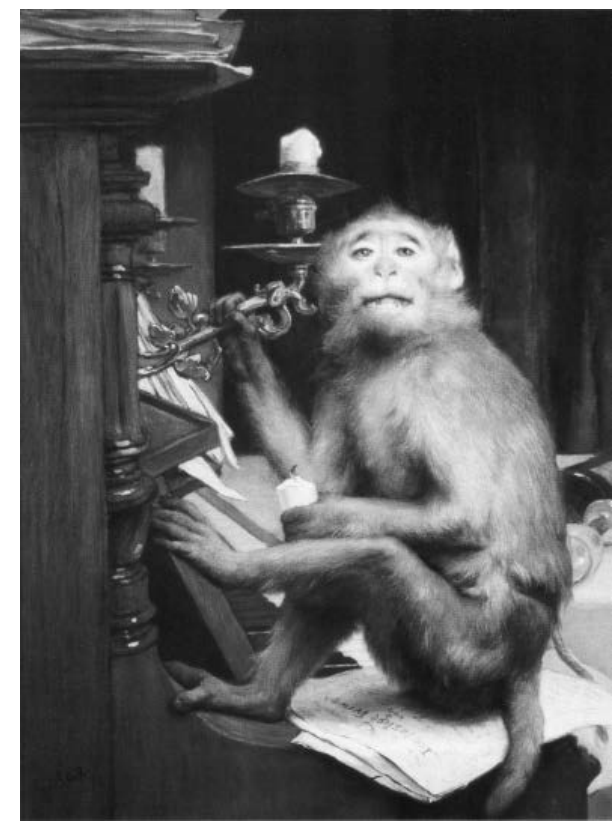

Př. 9 Gabriel von Max, Opice u klavíru, po 1905, olej na dřevě. Soukromá sbírka. Foto Martin Hahn.

tvarnou terminologii najdeme analogii již v roce 1780 , kdy je doložen pojem Tongemälde pro hudbu usilující o líčení krás přírody; toto uvažování je příznačné také pro programní hudbu Hectora Berlioze či Franze Liszta a pro teorii umění kolem roku $1900 .{ }^{53}$ Mladý umělec tak svým cyklem hudebních fantazí́ rozklenuje oblouk mezi romantismem a symbolismem; mohli bychom přitom uvažovat o specifické tradici „temného romantismu“, ostatně na letošní pařižské výstavě věnované tomuto fenoménu, který definoval Mario Praz, byl Max zastoupen. ${ }^{54}$ Romantickým hrdinou umění, jehož kult kulminoval v době kolem roku 1900, byl jeho oblíbený skladatel Ludwig van Beethoven. Maxe inspirovaly také klavírní skladby Mendelssohna-Bartholdyho, Liszta, či Schumanna, ale v Beethovenových sonátách našel nejurčitější vyjádření specifických emocí a duševních stavů. Jejich subjektivně motivovaná výtvarná znázornění nabídl překvapenému uměleckému publiku.

53 I. I. Engel, pojednání Über die musikalische Malerei, 1780; Eduard Wölfflin, přednáška Zur Geschichte der Tonmalerei, 1897. Viz WÜRTENBERGER, c.d., s. 75.

54 FABRE,Côme - KRÄMER, Felix. L'ange du bizzare. Le romantisme noir de Goya à Max Ernst, katalog výstavy. Paris: Musée d'Orsay, 2013. 


\section{Př́loha}

Gabriel Max

Beethoven, Mozart, Haydn

Beethoven ist einseitiger, subjektiver als Mozart, wo offenbart die Welt seines eigenes Inneren. $[\ldots]$

Im Gefolge größerer Bedeutung des Inhalts sehen wir das Streben nach möglichstere Bestimmtheit des Ausdrucks, wodurch die reine mit dem Wort nicht verbundene Tonkunst für die Darstellung ganz bestimmter Seelenzustände beförchst [beförderlich?] wurde. Früher bei Hayden und Mozart war das Werk der Instrumentalmusik überwiegend ein freies Tonspiel von unbestimmteren allgemeineren Ausdruck. Beethoven aber zeichnet bestimmte Situationen, schildert deutlich erkennbar Seelenzustände und steigert damit das Instrumentenspiel zu einer Bestimmtheit des Ausdrucks, die esfrüher nicht lassen hatte [?]. Eng damit in Verbindung stehtdie poetische Dichtung welche er verfolgt, das Streben, ein poetisches Bild dem Hörer vor der Seele zu führen, eng damit in Verbindung auch die dramatische Lebendigkeit seiner Compositionen, welche durch die zur Darstellung kommende Entfaltung des Inhaltsherangewachsen wird. Früher, bei Mozart, war eine verständig - logische Ausarbeitung das die Gestalt des Tonstückes bestimmende; jetzt teilt diese Behandlung zurück, ist nicht mehr das Leitende, allein Gestaltende, und Tondichter folgt seinem poetischen Vorwurf, indem er ein großes Seelengemälde, reich an unterschiedenen Stimmungen, an uns weiter führt.

Beethoven - Nächstenliebe
Mozart - Geschlechtsliebe
Hayden - cosmische Liebe

Hayden abgeschlossen in kindlich-patriarchalisten Zuständen, Mozart in bunten Mannigfaltigkeit des Lebens, Beethoven der einsame führt in die innere Welt.

Beethoven wurde als der Beherrscher der neuesten Zeit bezeichnet. Es sind alte pedantische Vorurtheile, wenn man sich einer Malerei aus dem Gebiete der Tonkunst widersetzt, wie sie durch Beethoven zur Ausbildung gekommen ist; wenn man diese höhere, poetische Handlung mit poetischer Echos der Erscheinungen wechselt. Tonmalereioder eine bloß äußerliche Abgemachung sinnlicher sowohl wie geistiger Objecte ist allerdings das Widerlichste, was man haben kann; einige Tonsetzer sind im diesen Fehler verfallen. Tonmalerei aber, welche in dem scheinbar äußerlichen Entlehret [?] ein Innerliches, Seelisches zur Darstellung bringt, wie wir das bei Beethoven sehen, ist nicht bloß etwas Berechtigtes, ist in der That ein Fortschritt.

\section{Ediční poznámka}

Text pochází z Maxova zápisníku z doby vídeňských studií kolem roku 1860 a dokládá genezi ideové koncepce jeho kresliŕského cyklu Obrazové fantazie k hudebním skladbám. V záhlaví uvedený název je sekundární, současný. Nestránkovaný zápisník je uložen v GNM Norimberk, DKA, NL Max, I,B-211.

Za pomoc při přepisu obtížně čitelného textu, který si umělec pořídil pro vlastní potřebu, autor článku děkuje kolegovi Dr. Tomáši Černušákovi. Text je upraven do současné němčiny, až na ojedinělé výjimky (např. Composition, Hayden, That atd.), opraveny jsou zjevné omyly (schildert místo schildet, Instrumentenspiel $\mathrm{m}$. Instrumendespiel, widersetzt $\mathrm{m}$. wiedersetzt).

Za podporu výzkumu na tomto tématu udělením jednoročního badatelského grantu autor děkuje děkanovi Filozofické fakulty Masarykovi univerzity v Brně.

Aleš Filip (16376@mail.muni.cz) je historik umění, absolvent oboru Věda o výtvarném umění, vyučující oboru Sdružená uměnovědná studia na Ústavu hudební vědy FF MU v Brně. 


\section{ABSTRACT GABRIEL VON MAX CYCLE PHANTASIE-BILDER ZU TONSTÜCKEN}

The Munich, Czech born painter Gabriel von Max (1840-1915) created the cycle Phantasie-Bilder $z u$ Tonstücken in the years 1861-1862, i.e. at the time, when he finished his study at the Academy of Fine Arts in Vienna. Within the cycle, he connected his drawings with five piano sonatas by Ludwig van Beethoven, Lieder ohne Worte and oratory Christ by Felix Mendelssohn-Bartholdy, piano compositions by Franz Liszt, Robert Schumann etc. Max appreciated an emotive impact of instrumental music and aimed to achieve a similar effect through his drawings. Matching his drawings to concrete musical compositions was motivated for the most part subjectively, for the orientation of public, he appended a minute explanation to the first edition of his cycle (with photographic reproductions) in the year 1862. At this paper, the Max' cycle is analysed with the use of hitherto unexploited sources from the artist' estate at Deutsches Kunstarchiv (Germanisches Nationalmuseum in Nürnberg), but also through the summarisation of published interpretations and a detailed probing of drawings. Gabriel von Max continued a romantic tradition of an approach of painting and music and at the same time he begun to outline his presymbolistic concept of visual arts through this early work by him. The theme of the reception of music in the $19^{\text {th }}$ century is devoted a special attention at this paper.

\section{Key words}

Gabriel von Max, cycle of drawings Phantasie-Bilder zu Tonstücken, the reception of music in the $19^{\text {th }}$ century, Ludwig van Beethoven, Felix Mendelssohn-Bartholdy, romanticism and presymbolism

\section{Bibliography}

Beethoven compendium. A guide to Beethoven's life and music. Barry Cooper (ed.). London: Thames \& Hudson, 1991.

BRONFEN, Elisabeth. Over her death body. Death, feminity and the aesthetics. Manchester: Manchester University Press, 1992.

ČELEBONOVIĆ, Aleksa. Bürgerlicher Realismus. Meisterwerke der Salonmalerei. Berlin: Propyläen-Verlag, 1974.

FILIP, Aleš - MUSIL, Roman. Ein wahrer Homunkulus in der Tierwelt. Gabriel von Max' Affenbilder. Umění, 2010, roč. 58, s. 294-311.

Gabriel von Max (1840-1915). Aleš Filip - Roman Musil (eds.). Řevnice: Arbor vitae, 2011.

Gabriel von Max. Be-tailed cousins and phantasms of the soul. Jo-Anne Birnie Danzker (ed.). Seattle: Frye Art Museum, 2011.

Gabriel von Max. Malerstar, Darwinist, Spiritist. Karin Althaus - Helmut Friedel (eds.). München: Hirmer, 2010.

GOTTDANG, Andrea. Beethoven im Malkasten. Beziehungen zwischen Landschaftsmalerei und Musik um 1850. In: Musicologica astriaca, Bd. 25. Die Vorstellung von Musik in Malerei und Dichtung.Barbara Boisits - Cornelia Szabó Knotig. Österreichische Gesselschaft für Musikwissenschaft, Wien 2006, s. 33-53.

GOTTDANG, Andrea. „Vom Schalle geweckte Träume.“ Gabriel von Max und die Musik. In Gabriel von Max. Malerstar, Darwinist, Spiritist. Karin Althaus - Helmut Friedel (eds.). München: Hirmer, 2010, s. 56-63.

GOTTDANG, Andrea. Vorbild Musik. Die Geschichte einer Idee in der Malerei im deutschsprachigen Raum 1780-1915. München: Deutscher Kunstverlag, 2004.

MANN (LEHMANN), Nicolaus. Gabriel Max. Eine kunsthistorische Skizze. 2. upr. vyd. J. J. Weber, Leipzig: 1890.

MAX, Gabriel. Erläuterungen zu den Phantasiebildern zu Tonstücken. Wien: Jägermayer \& Companie, 1862. 
MÜLLER, Rudolf. Künstler der Neuzeit Böhmens. Biographische Studien. XIII. Gabriel Max. Mittheilungen des Vereines für Geschichte der Deutschen in Böhmen, 1889, roč. 27, s. 289-326.

REITHAROVÁ, Eva. Josef Mánes. Odkaz malírů Mánesovy rodiny. Praha: Eminent - Patrik Šimon, 2005.

RICHTER, Margaret Mary. Gabriel Max. The Artist, the Darwinist and the Spiritualist. (phil. dissertation, vedoucí práce Robert Rosenblum) New York University, 1998.

Secession 1892-1914. Die Münchner Secession 1862-1914. Michael Buhrs (ed.). München: Museum Villa Stuck, 2008.

Shepherd $W \& K$ Galleries. European Paintings, Drawings and Scuplture [online]. [Cit. 12. 9. 2013]. Dostupné z: <http://www.shepherdgallery.com/view_image.html?image_no=419>.

STILJANOV-NEDO, Ingrid et al. Von Chodowiecki bis zur Gegenwart. Eine Auswahl aus der Graphiksammlung. Regensburg: Museum Ostdeutsche Galerie, 1993.

WEBEROVÁ, Susanne. Dobová recepce díla Gabriela von Maxe v Německu. In Gabriel von Max (1840-1915). Aleš Filip - Roman Musil (eds.). Řevnice: Arbor vitae, 2011, s. 260-283.

WITTLICH, Petr. Closed Eyes. Symbolism and new kapes of suffering. In Lost Paradise. Symbolist Europe. Jean Clair (ed.). Katalog výstavy. Montral: The Montreal Museum of Fine Arts, 1995, s. 235-241.

WÜRTENBERGER, Franzsepp. Malerei und Musik. Die Geschichte des Verhaltens zweier Künste zueinander - dargestellt nach den Quellen im Zeitraum von Leonardo da Vinci bis John Cage. Frankfurt am Main: Peter Lang, 1979. 